\title{
Genealogical And Cultural Fusion In The Muslim Community Of Pegayaman
}

\author{
Ida Bagus Putra Yadnya ${ }^{1 *}$, Made Dhanawaty ${ }^{2}$, Made Wiasti ${ }^{3}$, Nyoman Seri Malini ${ }^{4}$ \\ Udayana University Bali, Indonesia ${ }^{1234}$ \\ \{putra_yadnya@unud.ac.id ${ }^{1}$,md_dhanawaty@unud.ac.id², made_wiasti@unud.ac.id ${ }^{3}$, \\ seri_malini@fs.unud.ac.id ${ }^{4}$ \}
}

\begin{abstract}
People involved in cultural transitions due to migration must adapt to their new social environment and decide how and / or whether they will integrate themselves into the host culture. They have to cope with new cultural and social pressures and standards. This paper aims to show socio-cultural fusion in the continuity of life of the Pegayaman Muslim diaspora community. This research uses a qualitative approach with three methods including participatory observation, interview, and survey methods, supported by focus group discussion (FGD). The analysis was based on the axioms of cultural fusion theory proposed by Kim (2001) and Kramer (2000). The results showed that, in general, the Pegayaman community was formed through a genealogical fusion process between Javanese men and Balinese women through marriage. In the next development, what happened was not intercultural fusion or interfaith fusion, but there was a fusion between Balinese culture and Islam. This gave birth to a number of small fusions that gave color to the cultural and religious life of the Pegayaman community, including fusion in the culinary field, singing in the art of burdah, fusion in naming system, using Balinese first names, and activities in the implementation of religious holidays. Religion is at the heart of all existing fusion.
\end{abstract}

Keywords: community; cultural fusion; culture;genealogy

\section{Introduction}

When people come into contact with one another from different cultures and languages is accommodation, contact and assimilation (Persons, 1987). Contiguity of people that have different cultures push them seek ways to accommodate each other in reducing conflicts. Thus, contact forms intergroup relationships between various ethnic communities and when newcomers learn to accommodate a dominant group, a process of cultural assimilation occurs. So is the case in Bali. As a small part of Indonesia Bali has a unique culture inspired by Hinduism which is strengthened by the presence of a single language, namely Balinese (Agung, 2003). In Bali, apart from being a small island inhabited by Balinese ethnic, at least there are a number of other ethnic groups who settle and live, including Javanese, Bugis, Madurese, Sasak, Chinese and others. The cultural diversity of these newcomers finally gave 
its own color in the Balinese cultural framework. Judging from the phenomenon of language and cultural contact, research on the diaspora community in Bali is very interesting and significant to do. As a group of migrants, they are faced with a dominant culture, namely Balinese culture, which in principle has different styles, especially in the field of religion. This long interaction has led to a mixture of cultures between the two groups of people. How they develop adaptive behavior patterns in a broader socio-cultural context is an aspect of the diaspora that is very interesting to study.

Newcomers, regardless of their cultural heritage must in one form or another adapt to their new cultural environment (Ward et al., 2001 in Padilla and Perez 2003). The social identities they carry and the identities they develop in the new environment influence social cognition which in turn guides their behavior such as the clothes they wear, the food they eat, the people they associate with, the values they hold, and strategies that are used to accommodate new culture and people. In the context of diaspora in Pegayaman, Buleleng Regency, Bali Province, the interaction that took place over a long period of time led to a mixture of cultures between Balinese culture and the Muslim diaspora. This socio-cultural phenomenon can be analyzed using cultural fusion theory. Specifically, cultural fusion theory delineates how newcomers assimilate the prevailing society and keep up parts of their minority culture, while simultaneously the predominant or host culture likewise incorporates parts of the migrant culture into the predominant culture to make a blended intercultural personality (Croucher and Kramer, 2016).

The theory of cultural fusion is depend on four ideas that drive human conduct during the cycle of social combination. Firstly, the idea is coming from Kim (2001) that "humans have an innate self-organizing drive and the capacity to adapt to environmental challenges". The extent to which a person has a desire to regulate himself to adapt as a reaction to environmental challenges is related to many factors, including psychological / emotional abilities of newcomers (Kim, 2001, 2012), willingness to adapt, economic ability, political acceptance in host culture, and the strength of ties with minority communities (Croucher, 2008). The second assumption is that humans have an innate self-organizing drive and a desire to maintain their cultural identity while still adapting to the new environment through communication. The third assumption is that the incorporation of individual culture with the environment occurs in and through communication. The fourth assumption is that cultural fusion is an open system that makes it possible for many variables to interact to influence speed and fusion level of newcomers.

The theory relates to seven theoretical axioms showing patterns of interaction between repetitive variables. The first and most fundamental axiom of cultural fusion theory is that the incorporation of culture involves the acculturation and maintenance of culture in which newcomers to a culture are ultimately divided between adopting some new behavior or not (Kramer, 2000c). The second axiom is that cultural fusion brings intercultural transformation. The third axiom shows that intercultural transformation is manifested in the improvement of functional fitness, psychological health, and intercultural identity (Kim, 2001). The fourth axiom indicates that the transformation between newcomer culture and host culture facilitates and is facilitated by communication competencies. The fifth axiom is that intercultural transformation facilitates and is facilitated by participation in host and minority communication activities (interpersonal and mass). The sixth axiom is that pressure is placed on newcomers by the influence of dominant culture and is influenced by the degree of change between cultures of newcomers. The last axiom of the theory is related to the internal conditions of newcomers. Fusion involves changes in the newcomers; and some individuals are more open to change than others, and better prepared. Newcomers who know more about 
the host culture they are aiming for have more realistic expectations about their upcoming intercultural transformation (Croucher, 2008; Searle \& Ward, 1990).

The way migrants adapt will differ in relation to the way institutions, power, and discourse structure their experiences. In addition, while confronted with social, political, financial and social impacts outside their ability to control, they effectively pick how and how much they adjust, move in various headings in any event, when dependent on solid interests (De La Garza \& Ono, 2015). The phenomenon of cultural mixing can be explained through cultural fusion theory. This study aims to show how language, tradition, and identity are negotiated in a diasporic context in Bali Province. This research is meant to provide evidences to support cultural fusion theory as proposed by Croucher \& Kramer (2016) and how far the theory can justify new linguistic practices, new cultural traditions and new identities that emerge from tensions between global and local, connectivity and individuality, and the past and present within the diasporic context in Pegayaman, Buleleng regency of Bali as a case study. The study, in particular, is aimed at describing socio-cultural fusion in the development of the life of the Pegayaman community and the strengthened and neglected features of the fusion process.

\section{Methods}

This research is sociocultural research using a critical descriptive qualitative method. It is not intended to test specific hypotheses but instead describes "as it is" about Pegayaman Muslim diaspora community, in Buleleng Regency that has settled in Bali for more than a generation and has an migration history related to the existence of a ruling Buleleng kingdom in Bali. This research uses a qualitative approach with three methods including participatory observation, interview, and survey methods, supported by focus group discussion (FGD). Direct observation was meant to find out how the activities of the diaspora community in Pegayaman really are in their social life. The interview method was conducted directly by making contact or conversation with the informant as the resource person. Interviews were conducted using Indonesian and Balinese. The involvement of the Balinese language in interviews is to create closeness (rapport) between informants and researchers. The survey was conducted in one location by observing the diaspora community and giving a combination of open and closed questionnaires. The respondents' questions are related to socio-cultural fusion in the development of the life of the Pegayaman community and the strengthened and neglected features of the fusion process.

To maintain the validity and reliability of the data a focus group discussion was carried out, as a means for data triangulation. It was carried out by inviting linguists, anthropologists, and cultural experts as well as community leaders and diaspora communities in the research locations. This forum was meant to make some sort of data verification and obtaining additional information and expert judgment for revision and betterment of the result of the analysis. The qualitative and quantitative data are processed and reviewed applying sociolinguistic theory and cultural fusion. The result of analysis is descriptively presented in the form of narrative exposures about the quality of various symptoms that are studied extensively and deeply. While interpretative explanations are intended as an effort to interpret various phenomena. 


\section{Result and Discussion}

All diaspora communities coming to Bali, must have interacted with the local community or other communities who have settled in Bali first. So is the case with the Islamic community in Pagayaman. Two strong features attached to both parties are ethnicity and religion, male Javanese Islam and Balinese Hindu women. In the next development, what happened was not intercultural fusion or interfaith fusion, but there was a fusion between Balinese culture and Islam. Pegayaman community is formed by three ethnic groups, namely Javanese, Bugis, and Balinese. In addition to their mother tongue, they also brought identities that determined the way how they made a communication. The study indicates that in the process of socio-cultural fusion, cultural elements undergoing assimilation/ adaptation and forms of family solidarity in Pegayaman diaspora communities vary. From the recognition and study results of a key informant (interview with Ketut Muhamad Suharto, in FGD: 14/11/2020), the existence of Pegayaman is as a fortress of Buleleng Kingdom defending royal attacks from the south. During the four centuries of its historical existence from 1639, Pegayaman village has been able to create a local civilization. This existence can be seen from the distinctive characteristics that have been created by the values of acculturation and collaboration

The most distinctive and prominent feature of the Islamic community in Pegayaman Village is the use of the Balinese language in communication. The language has been considered as a mother tongue because it has been taught since childhood by the community. The use of Balinese actually could not be separated from the history of the forerunners of Pegayaman where initially many men married women of Balinese ethnic. Budarsa (2014) traced historically that the existence of the Pegayaman village community was inseparable from the history of the Kingdom of Buleleng which at that time was led by Ki Barak Panji Sakti. Mother-child interactions are so intensive in childcare that children are more familiar with Balinese than their father's native language. As a result, the use of the Balinese language has become so structured, massive and systemic and has developed to this day. Even Pegayaman community also confirmed that the holy verses in the Koran can be translated into Balinese, even the folklore such as bawang kesuna 'union and garlic' is also known here. The use of Balinese has penetrated aspects of Pegayaman people's lives as found in cultural elements such as livelihoods, agriculture, technology systems, naming, and religion.

In terms of the livelihood, Pegayaman Islamic community is not much different from Balinese Hindu society, namely farming, gardening, raising cattle and goats, while clove plants are the mainstay of Pegayaman Islamic community. In the field of agriculture, they are also familiar with the irrigation system technology, namely the subak irrigation system as found in Balinese culture. The irrigation system managed by this subak organization is related to the distribution of water from upstream or downstream water sources. In addition, they also know jelinjingan to refer to the waterways in the fields, penyakap (cultivators), majeg system (wholesale) in the sale of rice or field products

Related to living equipment or technology systems, Pegayaman people absorb some of the traditional technologies that are often used by the Balinese-Hindu community. One of them is a penarek and saab. Penarek is usually made of woven bamboo with a very small size and smooth. Saab is also a very important living equipment for Balinese people, especially in religious matters. Balinese cuisine that is often made by Pegayaman people includes sate gempol, lawar and urutan. They also used terms that are used by the Balinese Hindus in welcoming Eid such as penyajaan, penapean and penampahan.

The naming system for each Pegayaman Muslim community follows the naming system in Balinese society, which is based on birth order. This child's naming system has its own 
characteristics and is not found anywhere else. As a first name, they use names based on birth order like the people of Bali followed by an Islamic nuanced last name. The first child is given the name Wayan, the second child is Made or Nengah, the third child was Nyoman, and the fourth was Ketut. The Balinese first name is combined with Islamic name such as Hasyim, Siti, Raji, and so on. Thus the identity of a name that is quite unique is formed such as Wayan Hasyim, Nengah Siti, Nyoman Abdullah, Ketut Raji and so on.

As the time passed, cultural elements that are retained and the forms of rejection and purification carried out against host culture are noted. Some families have not pinned the Balinese nuanced name. Most of those who still use the name are the old people. Children born later rarely use the Balinese naming system, especially in families that have advanced level of education and economically classified as well-off.

In the religious field, the absorption process that occurs is more complex. The addition of elements of Balinese culture found in the religious fields of the Pegayaman community is seen during the celebrations of holidays such as Eid al-Fitr, Prophet's Birthday, and Eid al-Adha. The series of activities in welcoming this holiday is held like a Balinese holiday celebration. This series are added to their lives so that it has a different cultural character from other Islamic communities. This kind of celebrations is not found in other Islamic communities. Other additions are also found in the muludan alit tradition. In this tradition, people make a sokok base that resembles gebogan or pajegan (in Balinese culture). The fusion of cultural elements in the form of syncretism can be seen from the beliefs of Pegayaman residents about the presence of the Sacred Lord residing in Keramat.

In Pegayaman, there are also three-monthly rituals, otonan (6-month life cycle ceremony) like the Balinese. The ceremonies also used offerings from the coconut leaves, but the mantra is picked from the Qur'an. However, this kind of offering has gone as told by an informant: "When I was little, I experienced it. But now it's gone ". The loss of the offering element in the quarterly ritual can be understood as a process of purification. The use of offerings of this kind is considered inappropriate anymore since the Islamic education has begun to increase among Pegayaman people, especially those who had studied in Mecca. The most important thing for them is the meaning of the ritual and reading the verses of the Koran. The quarterly ceremony is still ongoing, but is only limited to thanksgiving by inviting relatives and neighbors to read the holy verses of the Qur'an. The loss of the offering element in this life cycle ceremony can also be understood as an effort to implement religious purification which is mainly carried out by the intellectuals in the Pegayaman community.

Although in general the process of cultural absorption occurs, the strengthened and rejection processes as well as neglected features of the fusion process in the area of belief can also be found. This rejection is not in the form of rebellion that is manifest or can be seen by the eye, but in a more subtle form. This rejection can be seen in terms of meat processing. Pegayaman people only want to consume meat that is treated in an Islamic way. In Islamic teachings, the people are required to consume meat that has been recited verses of the Qur'an so that it is halal for consumption. This has an impact on the refusal to provide food containing meat from non-Muslims. When Galungan for example, the Balinese who want to ngejot to the Pegayaman community will not be in the form of meat but fruits or cakes. In addition, Pegayaman people are also reluctant to buy food from non-Muslim residents for reasons of halal. They absorb Balinese culinary elements like lawar but do not accept it in totality. The critical attitude of the Pegayaman community is shown by replacing the basic ingredients of making lawar and not using blood in order not to violate religious rules. 


\section{Conclusion}

Specifically, the result of analysis indicates the applicability of the first and most fundamental axiom of cultural fusion theory that the incorporation of culture involves the acculturation and maintenance of culture. The community of Pegayaman Muslim assimilate the prevailing society and keep up parts of their minority culture, while simultaneously the predominant or host culture additionally coordinates parts of the newcomer's way of life into the predominant culture to make a blended intercultural character. There are two forms of social and cultural integration, which can be noted, namely the Muslim diaspora community change their socio-cultural structure to suit the Balinese culture and society and mixing the dominant culture with the immigrant sub-culture of the Muslim community in such a way that a new culture is produced. They have received conduct that are generally pertinent to daily life, for example, garments, language, and other social propensities.

The results showed that, in general, the Pegayaman community was formed through a genealogical fusion process between Javanese men and Balinese women through marriage. Two strong features attached to both parties are ethnicity and religion, male Javanese Islam and Balinese Hindu women. In the next development, what happened was not intercultural fusion or interfaith fusion, but there was a fusion between Balinese culture and Islam. This gave birth to a number of small fusions that gave color to the cultural and religious life of the Pegayaman community, including fusion in the culinary field, art, fusion in naming system, using Balinese first names, and activities in the implementation of religious holidays. Religion is at the heart of all existing fusion. Islamic marriage for the family, (a) lawar is a culturally accepted variant of food, but halal is its essence, (b) singing in the art of burdah, the kidungan music genre does not matter, the essence is in the lyrics that contain Islamic teachings, first names are only peripheral the point is in Muslim names, (c) the form of gebogan is not a problem, the point is that it functions in holidays. Activities ahead of the holiday are considered peripheral, which is the core of the id prayers and they clearly say that the preholiday activities are not worshiped.

\section{References}

[1] Agung, A. A. G. P. (2003). Bali, Obyek dan Daya Tarik Wisata. Denpasar: Dinas Pariwisata Provinsi Bali.

[2] Budarsa. (2014). Absorption of Balinese cultural elements by the Islamic community in Pegayaman village, Sukasada District, Buleleng Regency, Bali. Udayana University.

[3] Croucher, S. M. (2008). Looking Beyond the Hijab. Cresskill: Hampton Press.

[4] Croucher, S. M. (2011). Social Networking and Cultural Adaptation: A Theoretical Model. Journal of International and Intercultural Communication, 4(4), 259-264. https://doi.org/10.1080/17513057.2011.598046

[5] Croucher, S. M., \& Kramer, E. (2016). Cultural fusion theory: An alternative to acculturation. Journal of International and Intercultural Communication, 10(2), 97114. https://doi.org/10.1080/17513057.2016.1229498

[6] De La Garza, A. T., \& Ono, K. A. (2015). Retheorizing Adaptation: Differential Adaptation and Critical Intercultural Communication. Journal of International and Intercultural 
https://doi.org/10.1080/17513057.2015.1087097

[7] Kim, Y. Y. (1988). Communication and Cross-Cultural Adaptation: An Integrative Theory. Philadelphia: Multilingual Matters.

[8] Kim, Y. Y. (2001). Becoming intercultural: An integrative theory of communication and cross-cultural adaptation. Thousand Oaks: Sage Publication.

[9] Kim, Y. Y. (2012). Beyond Cultural Categories: Communication, Adaptation, and Transformation. In J. Jackson (Ed.), The Routledge handbook of language and intercultural communication (pp. 229-243). New York: Routledge.

[10]Kramer, E. M. (2000). Ressentiment and Racism: A Nietzschean reading of African American and Korean American conflict. In M. . Asante \& E. Min (Eds.), Sociocultural Conflict between African and Korean Americans (pp. 34-62). New York, NY: University Press of America.

[11]Persons, S. (1987). Ethnic studies at Chicago: 1905-45. Urbana: University of Illinois Press.

[12] Searle, W., \& Ward, C. (1990). The Prediction of Psychological and Sociocultural Adjustment during Cross-Cultural Transitions. Internotronal Journal of Intercultural Relations, 14, 449-464. Retrieved from https://pdf.sciencedirectassets.com/272065/1-s2.0-S0147176700X0079X/1-s2.0014717679090030Z/main.pdf?x-amz-securitytoken=AgoJb3JpZ2luX2VjEGEaCXVzLWVhc3QtMSJIMEYCIQCzeQcAx1vBI9D \%2F5lzmCns6H9n11zjo0sVSdS4U5cP\%2BvgIhALmR8bRGYuuHhpzAbtOMippW nhFwRwjPu6YaMex4y

[13] Ward, C., Bochner, S., \& Furnham, A. (2001). The Psychology of Culture Shock. Philadelphia: Routledge.

[14] Yadnya, I. B. P., \& Ardika, I. W. (2017). Dinamika Manusia dan Kebudayaan Indonesia dari Masa Ke Masa. Denpasar: Pustaka Larasan. 